\title{
Self Alienation of Adolescents with Visual Impairments
}

\author{
Rika Vira Zwagery, Akbar \\ Psychology Study Program \\ Universitas Lambung Mangkurat \\ Banjarmasin, Indonesia \\ zwagery@ulm.ac.id
}

\begin{abstract}
Psychologically, the social characteristics of a special need person have differences with normal individuals. Special need person having low self-esteem due to physical limitations tend to avoid social interaction with others. This study aims to identify the self-alienation of an adolescent with visual impairments. This study used a qualitative method with data collection methods used observation and interviews on the subject and significant others. The subject of the study was a 15year-old man who was blind. The conclusion of this study shows that adolescents who have physical limitations have a high selfalienation.
\end{abstract}

Keywords — self-alienation, visual impairment, adolescent.

\section{INTRODUCTION}

Sense of sight is one of the most important information sources for human because by seeing someone can understand something. Therefore, most of the information obtained by humans comes from the senses of sight, while the rest comes from the other senses. Considering the importance of eye function, if someone experiences interference in their vision, the ability of their activities will be limited. The information obtained will be significantly reduced compared to those with normal vision. For the blind, information from the outside world is conveyed through non-visual media. Therefore, the information can be understood through the somatosensation, sense of hearing and so on.

According to data from the Indonesian Ministry of Social Affairs in 2011, the number of people with disabilities in Indonesia reached $3.11 \%$ or 6.7 million people. Meanwhile, according to the Indonesian Ministry of Health, the number of people with disabilities is greater, namely: $6 \%$ of the total population of Indonesia. However, when referring to the stricter standards of the United Nations World Health Organization (WHO), the number of people with disabilities in Indonesia reaches 10 million. Meanwhile, the average number of people with disabilities in developing countries is $10 \%$ of the total population.

Based on a survey from PT Surveyor Indonesia (Persero), the highest population of people with disabilities is in West Java Province, around 50, 90\%, while the lowest population is in Gorontalo Province, around 1.65\%. According to the latest data (July 2012), the number of people with disabilities in Indonesia is listed as follows: Visually impaired 1,749,981, deaf/ speech impaired 602,784 people, quadriplegic 1,652,741 people, mental retardation 777,761 people. While based on gender, the number of male disabled population is more, which is around $57.96 \%$.

According to [1], blind people are individuals who have dysfunction in the sense of sight as the recipient of information in interpreting everyday events. The dysfunction of the senses makes a person stunted by his development. Blind people have a hindrance in cognitive, social and emotional development. They have various sources of stress that make them classified as individuals who have high-risk factors. Various developmental obstacles are experienced due to limitations in the learning process [1]. The problems that exist in blind children tend to be more complex when they become teenagers. It is because in adolescence there was a big physical change. Adolescence is a transition period among childhood to adulthood so that a high adjustment is needed. At this time, teenagers experience development reaching physical, mental, social, and emotional maturity. As social beings, blind people have the need to live and interact with others. However, limitations and physical deficiency make them less able to adjust to the social environment because they have relatively low self-esteem. Basically, blind youth have the same needs as other normal teenagers [2]. This similarity can be seen from the need for security, affiliation, affection from others, being accepted and need for education. Therefore, actually, people with visual impairments can participate in activities carried out by other people but need a good adjustment to be accepted by others. This is supported by the opinion of [1] that physical conditions not only allow children to follow reasonable activities for children of their age but also determine the attitudes of those around them. In general, people with visual impairments are often portrayed as figures who have disadvantages. Many problems arise as a result of a person's physical disability, both with regard to issues of appearance, association, and family issue. A blind teenager will face a difficult time. The deficiencies he experienced will make teenagers feel embarrassed, insecure, not confident to socialize with their environment and feel the world has become strange [2]. According to [3], someone who experiences disability often has problems in social interaction, all with parents, family, colleagues or with peers. Feelings of isolation can be referred to as self-estrangement, Fromm states self-alienation as the world (nature, objects, another man, and himself) have become strange [4]. Alienation/self-estrangement means losing 
the heart's impulses to associate, losing creativity, losing control of actions, losing autonomy, and in short destroying the individual's own potential [5]. According to [6] self-alienation is a problem most often experienced by teenagers. Selfalienation is a feeling of not being part of anything and a feeling that no one cares about anything that happens to us [7]. Mann defines estrangement as a state or isolated experience of groups or activities where one must have or where one must be involved [8]. Reference [9] formulated self-estrangement as a way of being (the mode of life) in humans in living themselves, as something foreign. The man has separated from himself, so that he no longer lives himself as the center of his world, the creator of his own actions, whereas actions or consequences of that have turned into something he obeys. Estrangement is a subjective feeling and foreign feeling towards the surrounding environment [10]. Based on the description above, the researcher is interested in knowing more about feelings of alienation in blind people who will be answered through research entitled "Overview of Self-Alienation on Blind Youth".

\section{METHOD}

This study employed a qualitative research method. The data was obtained by using interview and observation techniques. The type of interview used in this study was a semi-structured interview, in which this type of interview belongs to the in-depth interview category. The interview in this study was conducted both with the subject and significant others who were close friends of the subject. Interview with the subject aims to obtain and reveal the data studied in this study, while the interview with significant others aims to obtain supporting data that has not been revealed from the interview with the subject, as well as to find out how the state of the subject when facing problems in his life from the point of view of the significant others. The subject of this research was a 15year-old blind person

\section{RESULT AND DISCUSSION}

Adolescence is a transitional period characterized by physical, emotional, and psychological changes. Social life for adolescents is important because almost part of their time is spent together with peers. In this period, the needs of adolescents become complex, social interaction and teenage relationships become very broad [11]. Children begin to have the ability to adapt and develop cooperative attitudes to cooperate and notice the interests of others. In adjusting to the environment, adolescents have begun to show and recognize various social norms, which are different from the norms prevailing in the family. Therefore, a teenager with a visual impairment basically has a need to adapt to others, but it is limited because of the physical deficiencies they have. His physical deficiencies inhibit the acceptance of social information, making him less skilled in socializing. Blind children are individuals who experience whole visual impairment (the blind) or partially (low vision) which inhibits in obtaining information visually so that it can affect the learning process. It seems like this happened to the subject, that the subject experienced whole visual impairment that he suffered from the age of 9 months so that it inhibits the subject in receiving information in his daily life.

According to [12], the psychological characteristics of blind people are 1) suspicion of others; 2) feelings of irritability; 3 ) feelings of inferiority; 4) likes to fantasize; 5) critical thinking; and 6) courageous. Some characteristics exist in the subject such as suspicion to others when people help him, the subject feels strange and has a perception that he was insulted in the crowd. Subjects have a feeling of inferiority which is characterized by lack of confidence when dealing with other people, and this causes the subject to be an individual who rarely associates with peers because they see themselves as different from others. The subject is also an individual who can think critically which is marked by when the subject is invited to do something, the subject thinks first whether what he is going to do is right or not. The loss of visual function will lead to the limitations of the blind to explore all the contents of objects and other people in the surrounding environment. A blind person will always wait for action from objects or other people before reacting [13]. In this case, the subject always expects and waits for help from others because the subject feels that he does not have the ability to do something by himself. Some characteristics of the subject that emerged showed that he experiences self-alienation because he faces obstacles in his social life.

Reference [14] states that self-alienation has five aspects consisting of powerlessness, meaninglessness, normlessness, social isolation, and self-estrangement. First, powerlessness that exists in the subject is the subject always ask for help from others because the subject feels when not asking for help with other people, the subject cannot do anything. Moreover, the subject always uses tools such as sticks in supporting his daily activities. Second, meaninglessness in the subject is when the subject has a feeling of remorse with what happened to him by assuming that it is unfair with what he experiences now. He also has the desire to be the same as others. In addition, the subject also has a pessimistic feeling where the subject feels that what he does will not be achieved due to the limitations he has. Third, normlessness exists in the subject that is characterized by the subject feeling unable to defend himself and also because of differences perceived by the subject, the subject assumes that the subject does not need to follow what others do. However, the subject never gets unpleasant treatment from the environment around him and does not blame himself with his limitations even though he used to blame himself. Fourth, social isolation perceived by the subject such as feeling indirectly not accepted by the surrounding environment is because the subject feels strange to his environment. In addition, when the subject was young he has experienced bullying, it caused the subject to become a closed person and withdraw from the association. The last, selfestrangement in the subject is marked by a feeling that whatever he does is not beneficial to him because the subject always looks bad at every effort he has made and also the subject often follows the wishes of others because he feels more comfortable.

The results of this study indicate that a blind person who is at the stage of adolescence shows the existence of selfestrangement caused by the physical limitations he has. This 
was also mentioned by [15] that a student who has physical limitations feels more alienated when compared to normal peers. Physical limitations can make a person withdraw from the environment because of a feeling of low self-esteem and weak self-confidence. One factor that influences a person experiencing self-estrangement is a poor impression on appearance. The appearance itself is a less attractive appearance that keeps him away from the social environment. As has been explained, someone blind has physical limitations so this can make a person avoiding to interact with others. Having physical limitations does not only make a person agitated by their physical activity but also affects them psychologically so that they are at risk of experiencing stress. Psychological pressure experienced by a person with visual impairment makes him experience self-estrangement [16]. According to [17], alienation is a form of resistance that a person has to maintain the sense of self that he has so that someone chooses to isolate himself to represent the feeling he has.

\section{CONCLUSION}

Based on the results of this study that has been done regarding the picture of self-estrangement in blind adolescents, it can be concluded that adolescents who have visual impairment experienced self-estrangement/alienation such as the existing aspects of powerlessness, meaninglessness, normlessness, social isolation, and self-estrangement. Adolescents who have physical limitations have a high sense of self-alienation because they withdraw from relationships and have negative perceptions of the environment.

\section{REFERENCES}

[1] S. Somantri, Psikologi Anak Luar Biasa. Bandung: PT. Refika Aditama, 2007
[2] M. Masna, "Resiliensi Remaja Penyandang Tuna Netra pada SLB A Ruhui Rahayu di Samarinda," eJurnal Psikologi. vol. 1, no. 1, pp. 48-57, 2013.

[3] S. Kef and M. Dekovic, "The role of parental and peer support in adolescents well-being: a comparison of adolescents with and without a visual impairment," Journal of Adolescence, vol. 27, pp. 453-466, 2004.

[4] R. Schacht, Alienasi Pengantar Paling Komprehensif. Yogyakarta: Jalasutra, 2005

[5] S. Setiadi, Perilaku Konsumen. 2010.

[6] M. R. Brown, K. Higgins, and K. Paulsen, "Adolescent alienation: What is it and what can educators do about it?" Intervention in School and Clinic, vol. 39, no. 1, pp. 3-9, 2003

[7] J. M. Henslin, Sosiologi dengan Pendekatan Membumi. Jakarta: Erlangga, 2007.

[8] E. B. Johnson, Contextual Teaching and Learning Menjadikan Kegiatan Belajar-MengajarMengasikkan dan Bermakna. Bandung: Kaifa Learning, 2011.

[9] E. Fromm, Masyarakat yang Sehat. Jakarta: Yayasan Obor Indonesia, 1995

[10] A. K. Bekhet, M. Elguenidi, and J. A. Zauszniewsk1, "The Effects Of Positive Cognitions On The Relationship Between Alienation And Resourcefulness İn Nursing Students İn Egypt," Journal Of Issues In Mental Health Nursing, vol. 32, pp. 35-41, 2011.

[11] E. D. Papalia, S. W. Old, and R. D. Fieldman, Human developtment edisi kesembilan. Jakarta: Kencana, 2008.

[12] S. Rudiyati, Pendidikan Anak Tunanetra. Yogyakarta: Pendidikan Luar Biasa Fakultas Ilmu Pendidikan Universitas Negeri Yogyakarta, 2002.

[13] H. Hidayat and S. Suwandi, Pendidikan Anak Berkebutuhan Khusus. Bandung: PT. Luxima Metro Media, 2013.

[14] K. Fishman and L. Langmen, "Alienation," Jurnal Sociopedia Isa, pp. 110,2010

[15] M. R. Brown, K. Higgins, T. Pierce, E. Hong, and C. Thoma, "Secondary students' perceptions of school life with regard to alienation: The effects of disability, gender, and race," Learning Disability Quarterly, vol. 26, no. 4, pp. 227-238, 2003.

[16] C. M. Ifeagwazi, J. C. Chukwuorji, and E. A. Zacchaeus, "Alienation and psychological wellbeing: moderation by resilience," Social Indicators Research, vol. 120, no. 2, pp. 525-544, 2014.

[17] S. J. Mann, "Alternative perspective on the student experience: Alienation and engagement," Studies in Higher Education, vol. 26, no. 1 , pp. 7-13, 2001 